Godwin Aondofa Ikyer

Godwin Aondofa Ikyer is affiliated to the Department of English and Literary Studies, Federal University

Wukari, Taraba State, Nigeria.

Email: aondofa@fuwukari.edu.ng; ikyeraondofa@gmail.com
Deep digital poetry: Interrogating Tiv oral poetry within postmodernity

\title{
Deep digital poetry: Interrogating Tiv oral poetry within postmodernity
}

Poetry is one of the most vibrant artistic forms for socio-economic and political reconstruction of society among the Tiv of North Central Nigeria. The poets fix themselves in the forefront of arousing and propagating cultural consciousness, exposing vices, extolling virtues and personalities with such attributes, mobilizing people for unity and development, ensuring progressive change, maintaining social order and cohesion, unmasking socio-economic contradictions of class and polity, expressing the unheard voices of the voiceless in society and charting out a direction for the future of society. By reflecting the jeers, fears, aspirations, visions and general character of the society, they occupy a popular place and position in the social structure of Tiv society and their poetry is reinvigorated, in the usual popular way, in the new sensibilities of the digital technology being they dynamic in thematic exploration, traditional or modern. This article presents an exploratory overview of Tiv poetry in its changing digital forms of "secondary orality" which not only preserve the material but transform its productive, aesthetic and performance bounds to unending digital spaces creating in the wake a new character, a special effect, a new transmitting and storage pattern and the commodification of an individual's creations. The paper finally locates digi-orature, this new way of interrogating oral poets and their creations, within the ambience of postmodernity capable of attracting audiences outside the Tiv linguistic and geographical space. Keywords: digital oral art forms, Nigerian literature, postmodernity, Tiv poetry.

\section{Introduction}

In the early period of human interaction, activity, behaviour, and reaction in the process of communication, information was carried out in smaller groups through the representative forms of oral performing arts. A popular saying of the Greeks is that true democracy can only be possible within the sound of one man's voice (Anifowose and Enemuo 141-2). This conception rests on the understanding that communication and understanding are possible within small group and by faceto-face communication, which made Greek city-state particularly democratic. Oral art forms and folklore also revolve their means of expression and information dissemination through the power of the word. The poets were at the helm of the arts in expressing emotions, ideas, values and the ethos of society. The oral poet created public attraction to himself and his art that he influenced the moral, cultural, political, economic, and religious codes and direction of his society. These poets were the conscience of their society. 
Two events, relevant to the present study, led to the gradual dislocation of this word, figure, sign and performance society. The first is the invention and flexible nature of industrial technology which created a media mediated reach between the artist and his audience, the mass production of materials and automation culture of information distribution and consumption. The second is the proliferation of multiple layers of multimedia communication. Following older forms of communication formats such as newspapers, radios, tape- and video-recorders and televisions, contemporary forms include personal computers, telephone handsets, the Internet and portable instruments such as the iPhone and iPad. Others forms of communication engage the sensory functions of humanity such as hearing, smelling, touching and sight (see also Dexter 3-4). Multimedia has evolved to be a dynamic space incorporating multidisciplinary spheres involving drama, dance, performance, literature, visual art, film, and varieties of the personal computer to mention a few. This broader multidisciplinary scope of multimedia maybe what Richard Wagner imagined in his phrase of Gesamtkunstwerk or "synthesis of the arts" (Blake 491-2).

Multimedia has risen to become one bald postmodern reality of preserving oral art forms and folklore, which is used to carry out research on emergent forms of cultural materials, i.e. recollecting narratives and performances as well as getting people entertained in these new forms. Oral art forms are now also recreated, reproduced and commodified in deep digital forms via images and audio on the web, through animation and photography, through video productions and performances or exhibitions in galleries. The oral poets have digital reproduction available to them. For increased engagement and motivation, oral performances can be polished in speech synthesis with technical and creative techniques capable of creating natural or human effects such as thunder, lighting, audience reactions (i.e. clapping, laughing or booing). The oral and the visual could be combined in linking text audio, video, animation and graphics through hyperlinked multimedia. This integrative and supportive hypermedia could relive narratives and performances, enrich texts in time past, in ancient and modern confluences, and recreate a history in a connective chain such that oral histories and culture could bounce back to cultural and modern reckoning.

The term "digital" is used here to incorporate all electronic forms of communication, which preserves past oral art records for further scrutiny. The word "interrogation" as used here concerns getting information from computer databases and mental recall. "Postmodernity" in this article refers to the developments that shape contemporary society such as the new technologies and the multimedia capabilities and in John Barth's words "a continuation but modification of cultural modernism" (in Rice and Waugh 324). The Tiv are the fifth largest ethnic group in Nigeria and are resident mostly in North Central Nigeria, particularly the Benue valley. They can be found in other parts of Nigeria and Southern Cameroon. 


\section{Digi-orature: Oral art forms, folklore and multimedia}

Orature, an African nomenclature for oral art forms or verbal arts, is rooted in folklore (Liman, "Orature"; "Re-negotiating" 4-5). The broad categories of orature include tales, riddles, poetry, proverbs, songs, legends, myths, plays, and performances. These intertwined categories express and communicate human, spiritual and cosmic interactions and relationship. To Okoh (236) "oral literature constitutes a pleasurable mode of learning. In other words, there are other possibilities beyond this element of enjoyment." Gunner (67) asserts on the oral weight of the art that:

Orality need to be seen in the African context as the means by which societies of varying complexity regulated themselves, organize their present and their pasts, made formal spaces for philosophical reflections, pronounced on power, questioned and in some cases contested power, and generally paid homage to "the word," language, as the means by which humanity was made and constantly refashioned.

With multimedia and deep digital technology, the "small groups" of oral interactions and performances can be expanded to "large groups" and global cultures. Digital advances in the changing character of the oral text have had significant attempts by scholars at creating terms suitable to the digital formats of oral art products. The term "orature" itself has been a conceptual development from the contestation of "pure" orality and literacy, later described as the "great divide theory" (Finnegan, "Literacy" 112-4) and the African oral forms' extension as a field of folklore which has been an appendage of anthropology over a long period of time (Ahmed 186-98, Aliyu 51-6, Babajo 9-13, Zirimu and Bukenya, 88-105). The oral-literacy dichotomy created a chasm between tradition and modernity and that of the African world and the Western world, a divide which sparked questions to the place of orality and that of the eroding quality of cultural heritages (Wali 13-5; Merola 80-2). Pio Zirimu, a Ugandan linguist, became an "oracy activist" and coined the term "orature," "the study of oral art forms" (Zirimu 95) to fashion out a new platform of discourse of oral products and to discourage the exaggerated colonial relevance of the written word against the spoken word (Ong 2-3; Liman 155). Culture and artistic modes of expression and experience are rendered orally, and information and knowledge are committed to memory and dispensed through oral apprenticeship and mentoring. The term "orature" came against the negative connotations of oral literature not "attaining the norm of full literature" (Finnegan, The Oral and Beyond 90). Orature thus emerged during the postcolonial independence, "in its own right" (Finnegan, The Oral 190) or suffering the "consequences of literacy" (Goody 304-5). The term orature is closely related to an earlier established one, "verbal arts" in its centrality of the vocal rendition of information. In fact, the term vocalite formulated by Zumthor appeared in Collectif (13) set out to establish the vocal realization of traditional oral art products. 
Another term, vividly explained by David Coplan in his analysis of migrant workers' songs in Southern Africa is "auriture". The term while emphasising the voice, also introduces the vital sensory organ of hearing. By the inclusion, the performer and audience are brought to a significant interaction and relationship between performers and the audience. To Coplan (8-9), the concern of "auriture" is "the emphasis on the ears of the hearers, who include both performer and audience, and hence, properly, on the intended and experienced aesthetic transaction between all participants in a performance event."

Significant attempts at confronting oral textual and performance qualities include concepts such as "oracy", "orauarality", and "oraliture". Others are "literary orature" (Swanepoel 121), "lit/orature" (Fox 376), and "oralature" (Rosenberg 75). The widened "dimensions of sound" as Finnegan (The Oral 191) puts it collaborates with the speaking mouth, the hearing ear and the "auditory ambience." Peek (474-94) refers to the new trend as "auditory arts," which to Kishani is "oraural", "oraurality" and the adjective "ouralize". And closely related to "digi-orature" in this paper is Kaschula's "technauriture" or "technologized auriture" which examines "rap, dub poetry, slam and contemporary Xhosa praises on radio, television, musically backed audio discs, CD-ROM and the web". The term is further expanded by Daniela Merola and others in their Multimedia Research and Documentation of Oral Genres in Africa (2012). Ngũgĩ wa Thiong'o (85) provides the term "cyborature" to hybridize oral cultural forms, literate culture forms and the digital culture forms. This, he hopes, will generate "a host of endless possibilities." According to Finnegan (The Oral 191) "Each term alerts to slightly different viewpoints but what all have in common is a move away from more verbally texted dimensions into an appreciation of voiced and sonic qualities, the auditory-sometimes multi-sensory-relations between participants, and the active dialogues of performance. [...] Such terms have decisively widened recent approaches to conceptualizing oral forms."

Conceptualizing oral texts propels the researcher to look beyond the strictly old and oral forms to their enduring qualities and reach. It is obvious that changes have taken place in human and material developments across the continents of the world. The African oral texts have created for themselves new horizons of expansion from their communal or group usage, broadened their production and consumption capacities, and ensconced themselves in the editing and creative innovations of the new media thereby changing the very character and quality of oral text productions beyond the Oral Moment, beyond the local oral aesthetics, and beyond their traditional strongholds of "tribal inheritance" or genre classifications. The notion of local closure and fullness has given way to hybridization of art forms or categories, opened up performance moments, created authorship concerns, produced multifaceted versions and illuminations of the same oral art product, and ensured a mixed identity of values and intersection, being the changes and processes inherent in contemporary existence. 
The innovations and changes are facilitated by a mix of new media which outlook has promoted the "traditional" oral texts and moved them to another level of production, consumption and documentation. The oral text in form of a poem, folktale, legend, or myth may be contextualized as a digital music text, a film, dance drama, performance, radio, television or social media material in digitally crafted versions to a variety of audiences across the world unrestricted of race or language. This digital contextualization and diversification of oral art products is the new trend and style of cultural production that has opened up vistas of advertising, youth engagement, globalization and commercialization, social interaction and entertainment beyond the oral text, beyond literacy, beyond the traditional, beyond a century, beyond the tribal, and beyond the language to a global connect, to an economic sensibility and productivity, to a creativity dexterity, and to audience fluidities of concern and expression. Local flavours are sure to exist in the new forms, but the multimedia productions may continue to manipulate the products to reflect contemporary purposes.

The interface between orature and the new digital media has created a transdisciplinary attraction, a co-created version, a new horizon of comprehending oral art products, a new economic focus of interest, a new pattern of production and consumption, a new authorial participation, identity and perspective, a new linguistic blend, a digital audience frame, a new model of oral text, and an essentially emerging voice and attractive research interest for exploration by all members of the global community. This is also another point to which the term digi-orature becomes relevant. The oral art forms have become complex in their current production via the digital media and requires a catchy tag to recognize its changing character and dynamics, and its emerging potentials and possibilities.

Multimedia has created a new range of structural, technical, creative, narrative and performance modes in the areas of literature, folklore, performance arts (drama, music art, dance), media film and visual arts exploring such forms' flexibility and dynamism. Multimedia has come to bridge traditional and modern cultures. With the advent of multimedia technology, oral artists have joined in the prevailing attitudes and tastes of the time to digitise, preserve and share their collection of oral narratives and performances but also to distribute performances to get the wider public-to see, hear and touch a wide range of their cultural heritage. Versions of traditional Tiv oral poetry are reintroduced in fragments or wholly; revised, revitalized and restructured in deeply digitised formats. Deep digitisation provides a glimpse of the life and culture of the Tiv people, as will be demonstrated in this article.

\section{The Tiv cultural history}

It is imperative to take a brief look at Tiv cultural history in light of the South African scholar, A. C. Jordan's observation that "if literature reflects the society which produced it, then understanding the social forces at work in that society is vital to 
appreciating that society's literature" (viii). The Tiv of North Central Nigeria are an egalitarian society in nature whose religious practices revolves around the concept of Tsav which identifies good and bad governance yet believes in the existence of one Almighty God. They are said to be farmers, hunters, and blacksmiths. They also engage in the production of creative arts and craft works. Their arable land, their forests and tall bushes, and their main occupation of farming are probable reasons for these traditional engagements. Rupert M. East (in Akiga 13) in his translation of Akiga's Story (1939) states somewhat patronisingly that the Tiv "[a]re stockily built, virile race of farmers, whose two great aims in life are to fill their yam stores and granaries with food, and their homes with children: an independent people, who have little respect for princes...."

The Tiv are patrilineal in social structure and resolve conflicts through their Council of Elders, the Ijir. The maternal family could be a safe haven for people who feel strongly aggrieved by this patrilineal, agnatic lineage. The kwav, age-grade is another strong intervening force in the resolution of conflicts especially involving members.

The landmass of the Tiv stretches a little above latitude $\mathrm{N} 6.3^{\circ}$ to $\mathrm{N} 8^{\circ}$ and from $\mathrm{E} 8^{\circ}$ to $\mathrm{E} 10^{\circ}$ extending from the foothills of the Cameroon Republic mountains, the Sankwala Hills in the south to the "undulating plains" north of River Benue and an expansive span under the escarpment of the Niger, Bauchi and Plateau plains (see Adeiyongo 15-7; Hagher 18-27; Ker 8-9; Utov with Ioratim-Uba 7-8). The Tiv cultural narrative is orally generated and handed down from generation to generation through memories and "mental monographs", nourished by individuals, groups and generations.

\section{Tiv poetry in deep digital postmodernity}

Postmodernism, is "an epochal term for describing the period which allegedly follows modernity" (Best and Kellner 2). The notion of postmodernity is not historically periodic but suggests "a way of thinking, or even no-thinking, more than it defines a particular period in time" (Cohen 281). Postmodernism encompasses many discursive fields of study in arts and social sciences. Within the cultural ambience of postmodernity - the contingencies of fragmentation of oral art forms, the attitudes of the youth to deep digital surrender, the presence of the digital web and its cocoon of coded messages-have shifted descriptive, analytical, research, aesthetic and entertainment discourse of oral art material and cultural products to these diverse multimedia productions and the commodification of cultural materials as they engage irony, parody, pastiche, collage, fragmentation and self-reflexivity to capture and revitalize existing and dying oral art forms.

The first place of call for multimedia technology is the audio reproduction of the Tiv national anthem for special occasions, especially ones celebrative in nature. The anthem goes thus: 
Yo o oo!

Ageba geba vakaa

Iwer ikar

On mba Tiv cii

Wuha duwe sha tembe yô

Ikyur ior ihembe ayem ve!

Begha ande sha hyande ve!

Inyaregh ki bough ki kume

Er ka wura yô

Ndyar yough yi yough ${ }^{1}$

Being audio signal-centred, from the equally new radio station, Ashi Waves 99.9 F.M, Katsina-Ala, Benue State, Nigeria, the point at which there is a simile comes with the sound effect depicting the thing likened to. Here one sees a rumbling of thunder at exactly the point of simile without distracting the clear sound of the words. For the younger generation, this acoustic stamping of effect is symbolic and creates an easier understanding of the smooth parallel of the word with the sound. Ashi Waves radio station, established in 2013, has also created two versions of the Tiv anthem, which come on air every morning and evening, one being the voice and African drum rendition, and the other being western, studio-based instrumental. The audience have come to identify with the instrumental version as it synergises with the anthem's wordings.

In music, there is a fragmented, adapted or complete versions traditional poetry in epigrams, elegies, lullabies, wedding poetry, professional songs, and praise songs hybridised through the techniques of parody, pastiche and college in studios creatively using synthesizers, mixers, computer software, and modern musical instruments to convert traditional oral art to contemporary tastes.

Here follows a sample of these innovations in Tiv traditional poetry. Traditional poetry like imaama ("performance name to check youth excesses") now becomes imaimai ("sound of a cat"), to threaten errant youth from engaging in uncultured acts. The song and the picture of a wild chalk-painted face are combined to drive home the desired effect:

Imaama o

Imaama

Ayo o imaama oo

Imaama ayo! ${ }^{2}$

The sound of a cat and the dark environment of the performance seem a threat to the children especially, being targets of such cautionary threats. The video display of the performance recreates the spirit of the precursor forms of the kwagh-hir and 
the Mammywater. The satire chween ("deep feeling") from the Tiv ceremonial comedy, Mammywater, and the popular Swange Music and Dance which satirises on the consequences of going against cultural codes is retitled oyoo ("Yes oh!"), with a hybrid of songs and a co-opted diction but retaining the thematic thrust. Here is an illustration of these hybrid songs:

Chween!

Iyol

Chween, chween!

Iyol sha aba

An or u dughun iyol

Za kaa wan ngô na

Iyol i sôô origbo sha ijuwa

Iyol sha aba! ${ }^{3}$

and

Tôo azembe wan shaala oo o

Ior iyevese!

Tôô igyuve wan sha aya oo o

Ior ifa asema! ${ }^{4}$

The second song is the original which is parodied by the pop artists, the Zanga Zanga of Africa, to engage people in discussion on the hardships in getting a wife and the consequences of adultery; in its parodied form it is rendered as follows:

Tôô azembe wan shaala oo o!

Kwas ngu sha azenger

Or aya ican ahungwa amin yô

Or ade kpaan ga! ${ }^{5}$

The "play poem" ka we afaga itumbur we ("If you don't know, foolery is made of you") is maintained amidst new musical accompaniments, compare the song:

Ka we afa ga itumbur we e!

Or ngu afa ga itumbur nan a a $!^{6}$

The satire Tyough ki iwa, or Igbo ya ("Dog head, an Igbo ate!") is given a new look and rendition; the satirical poem tôo tobi wa shaala oo! "Take the underwear, keep it up there") has a new version as well as the dance song ishor katse, Abayol oo, ishor katse ("Abayol, dance is by inheritance") is now turned into ishor ka se ("dance, we are! Abayol oh! Dance we are!"), to suggest the group's dexterous dance act. The song an agbe tôô a tôô! Oooo yioo ("who it has fallen, oh! There you are!") is revitalized by the musical group Zanga Zanga of Africa, into 
An agbe tôô atôô?

Oo oo yio ooo!

An agbe tôô atôô?

Or atôô yô nan nam a! ${ }^{7}$

Incorporated in this space are cultural traits in narratives and performance such as the costume of the kwagh-hir performance groups, the orshuwa ("narrator") narrator technique, the use of Tiv traditional cloth, the anger, and an intercession with natural light and electric light. These modifications have created an appealing digital orality, especially for the youth who appreciate this rediscovery of their cultural heritage. For instance, the Zule-Zoo pop musical group sings a refrain which is a pastiche of a song in a Tiv legend:

Mgba ikya, mgema bagu ve!

Mgba ikya, mgema bagu ve!

In the legend, a woman became the "spoiler of the land" as one elder, Tema Ji, narrated to me, by turning into animals to destroy people's crops on the farm fields. The original version was popularly sung at public social gatherings in the 1960s, 1970s and early 1980s. The song emanates from the punishment meted to a woman who becomes deviant by creating and singing her own song of "liberty":

Ne yimam ayima

Me zende kasua aingye

Adikpo ka London

Abaji ka Shitile e!

Mgba ikya mngema bagu ve!

Mgba ikya mngema bagu ve!

The Zule-Zoo group also has a pastiche of a kwagh-hir interlude song, made popular under the title "Necessary". The original title in Tiv is rhetorical, "ka keng kengoo?" ("Is it necessary?") Both versions run in parallel bilingual rendering, one line in Tiv followed by another in pidgin. Both versions are created in the contemporary urban environment. The original goes as follows:

Wan kwase we yô udoo ashe!

You this lady, you're beautiful

Man me er nena ver udoo amo?

How I go do you follow me?

"saa uyam chahur shi uyam mkulem man me doo awe"

"Unless you go buy soap, you go buy cream, I follow you"

Wan kwase kwagh ne ka keng keng a oo?

Yes, it's necessary! 
The pastiche has line additions and embedded with a new wave of modern thought on materialism. It runs thus:

Saa me zua inyaregh

Saa me yam umato

Ver udoo amo yee?

Wan kwase we yô udoo ashe!

You this lady, you're beautiful

Man me er nena ver udoo amo?

How I go do, I go love you?

Saa me zua inyaregh

Saa me yam umato

Ver me doo awe?

Unless I go get money,

I go get motor

You go love me?

Wan kwase kwagh ne ka keng keng a oo?

Hingir sha keng keng ee?

Is a necessary!10

One prominent oral poet, Obadiah Kehemen Orkor, whose latest work is presented mostly through multimedia networks, makes much use of synthesizers wrapped with modern musical instruments. Through his digitised poetry his rural patrons witnessing a process of cultural hybridisation as they gradually come to terms with these "strange" instruments, and computerised combinations of images and audio. Obadiah's collection titled Manna (2013) is suggestive of this new character which Tiv oral poetry (and many of its kind elsewhere in Nigeria) is assuming. Another popular Tiv poet, Augustine Tarker Number 1 Golozo, now mediated by radio stations across Benue state of Nigeria, states in his poem, "Iyange i Nigeria" (Nigeria's Day), in advice from colonial and democratic experience that:

Yange se lu boki ior nyian kpa

Ken inyon i dubu mom man deriutaan kar

Unyiin man akundu atar yô

Se pav iya

Hii iyange la zan zan hegen yô

Hemba "twenty-seven years"

Se ôron kwagh u mbavia yum yô se sôr tar ga!

Tyô yam ishangen ngi van

Yô de veren kwagh u nyar ken hemen

Isangen ior mba ve lu a inja yô 
Or alu a naira ga kpa nan adoo yum yô

Tyô yam ne sangen nan

Kpa m ôr myange ga a!

[...]

Ne ior mba tsughun ityô

Iyange yen shi duwe ve

Utsughun angbianev ee!

Ukimbir ôrun er:

"alu ne nam yô

Me er sha shima i tyô yam isoo yô."

Man asangen nan yô

Nan yem agba sôrun iche i ter unan

Hen pe sôrun igbinda la

Kpa ibunde oo! ${ }^{11}$

In another of Golozo's poems, even though composed and performed during the 1979 general elections in Nigeria, is still made relevant in contemporary elections in Tiv society. In spite of the obvious leadership incompetence stated earlier, Golozo still canvasses for voters to exercise their civic right and responsibility of voting in the following song rendered in English:

If you don't vote for the important man

Standing for president of Nigeria

Make efforts to vote for the state assembly elections

Nyamkyume Amenga, [i.e. the name of a person]

The saying people have that:

"I won't vote someone to buy a car

And throw dust on me,"

That saying is anti-development

If you return from the farm with the suffering encountered

You won't invite a brother to partake in your meals

Try and give your name

Now is time for voter's registration

Party politics is ahead.

The oral poet, Yanmuel Yashi, renowned for his "philosophical poetry" and "existentialist worldview" (Jenkwe 3, 24) sings about the open-endedness of poverty when he states in "Poverty blows me like a whistle":

Iorgwajime

Suffering blows me like a whistle

So I am stunted 
Even to my mother's home, I can't go

So I'll die of penury

My clan too doesn't favour me

I don't smile.

In the Tiv popular video films too, producers and directors, have recourse to deploying Tiv poetry and other oral art forms in their productions. Jikeme Emmanuel's film Gbenda Awambe (re-titled in English as Bloody is the Way) is a contestable but multimedia version of the legend of Takuruku, the progenitor of the Tiv and God. The work adapted Tiv myth and legend to suit Christian legends. Sammy Willas' film, Igboji man Sule (A Tiv man and his Fulani friend, 2012) is a parody of popular Tiv comic artists in the name of Achoonakupa, [i.e. the name of an actual Tiv comedian], and some may argue, a revitalisation in the "fool" fashion of a known Tiv satire, Botwev (Odd settlement). A film in similar strand is Isaac Akpooki's Ibumegh ki a Chigh Ga (Foolishness has no medicine, 2012) The film Ikyese kwaghyan (Food Basket of the Nation, 2012) directed by Williams Kwa refreshes in a visual and modern thought direction, the legend of Tiv and God. It also incorporates fragments from other oral art forms like poetry, riddles, epigrams, satires, proverbs, myths, and epic. Also vividly captured are the films Sev Av: Tiv legends (Dawn is here, 2010), Oradiguve (An instrumentalist, 2009), Mba vegbe icaver kpa Terkoron Ve (Those who have become useless, God sew them up, 2010), Tartor Wase (Our Heaven" 2011), Nigerian Wuese Ter (The Nigerian, praise God, 2013), Know My Name, 2013), and Adan Wade Kohol Ga (Adan Wade did not meet it, 2012).These films reflects the changing trends of postmodern documentation, presentation, sharing, and entertainment using oral art forms and how old wines are rebranded in new bottles of technology, in the overwhelming contest of postmodernity. Adan Wade Kohol Ga, directed by Anjira Solomon Nyiekaa, particularly created visual symbols reflective of Tiv society in birds like a "caged hen" about to hatch and in birds singing "me kpe a or me kpe a or" ("I will die with someone, I will die with someone") to suggest the entangled nature of tradition and modernity. Children's rhymes such as this one below are rekindled and brought back visually to the fold of the children's play arena:

Menamaoo

Tôô ankyo la nam a

Ngun u?

Mvende ye!

Ngun $u$ ?

Mvende ye!

Ngun $\mathrm{u}$ ?

Oon nam ase! $!^{12}$ 
Oratory skills and sage sayings are provided through a widow, Tagude, to her only son when she felt she could no longer hold her life saving breath. Also, children are once again made to sing the play song "ka nan ye luam sha nyam ivo? Or ne ya luam sha inyam igyo! ("Who has eaten food with goat meat? This one has eaten food with pig meat!"). With the song comes a return to the children's play arena of the past and connotes a celebration of sort through the emergent multimedia technology, revitalising some threatened traditional art forms, creating possibilities for cultural expansion and commodification, while establishing new trends of cultural and cross-cultural interaction.

\section{Conclusion}

The interface between Tiv oral poetry and multimedia is creating possibilities of experimentation and diverse forms of innovation. In gradual codification of this deep digital phenomenon, Tiv oral poetry is now being interrogated within this ambience of postmodernity such that a new approach of studying oral art forms may develop, what I call digi-orature, the study of oral art forms created through multimedia technology. Truly, through digi-orature, Tiv, African and indeed the world's marginal communities' oral art forms can be captured in their historical and geographical contexts. In the light of these technological advances, it is incumbent on researchers to approach digi-orature as a multidisciplinary discipline, exploring the symbiotic interaction between oral traditions and multimedia, developing conceptual and theoretical formulations to match this emerging trend.

\section{Notes}

1. An English translation may be rendered thus. Yes, oh / Trumpets sound / Shouts abound / All the Tiv sons and daughters / Fully dressed, walked gaily to space and so / People wander in wonder / The Lion found itself on the field / Evil money thunders / Like rain / Walk valiantly, valiantly. All translation from the original are mine.

2. "Imaama oh / Imaama !/ Here he is, here is imaama / Here is he!"

3. "Deep! / Bee! / Deep, deep [in effect or worth] honey on the bag / Looking for honey / Go tell his brother / Bees sting an Igbo man on the penis / Bee atop the sacks!"

4. "Take the vulture's child from the nest oh! / People should scatter oh! / [But] take the eagle's child from its nest oh! / People should think within themselves!"

5. "Take the vulture's child oh! / A woman is on the high horizon/And If a man suffers to descend with her, nobody should have sex with."

6. "When you display ignorance [without enquiring] / The one that display ignorance is a fool of sort!"

7. "Who, it has fallen and has found? / Oh! Oh! Yes oh! / Who, it has fallen and has found? / Whoever takes should give to me!"

8. "I have turned to a chimpanzee and converted to a monkey! / I have turned to a chimpanzee and converted to a monkey!"

9. "You have saved me [by setting me free of responsibility] / I will traverse the markets / Adikpo is London [market, north-east of Benue] / Abaji ka Shitile oh! [Shitile people' market] / I have turned to a chimpanzee and converted to a monkey! / I have turned to a chimpanzee and converted to a monkey!"

10. “Unless I have money / Unless I have vehicles / Before you can love me? / It's necessary! / Mine girl you're looking beautiful / You this lady you're beautiful / What will I do to get you to love me? / How I go do you go love me? / Must I get money? / Must I get vehicles? / Before you'll love me? / Unless 
I go get money / I go get motor / you go love me? / My girl, is this so necessary? / Has it become that necessary? / It's necessary!"

11. "In the past, we were friends with the whites / in the year 1960 / we became independent/ From that day till now / it is more than twenty seven years / if we keep on talking about others / we will not repair our land / my people, election is coming / don't put money first / elect people of good qualities / if one does not have Naira but is good / my people, elect such a person / but i have not foreclosed the issue / you deceitful people / your sun has risen again / to deceive your kinsmen/to keep on repeating that: "if you give me your vote, I would do as my kinsmen want" / but when elected / such a person goes repairing his father's compound / no one even thinks of repairing bad roads."

12. "Menama oh! / Take that dice and give me! / This one? / I said no! / This one? / I said no! / This one? / Yes, give it to me!".

\section{Works Cited}

Adeiyongo, John, Akôsu. A literary study of Tiv Anzaakaa. Ph.D. diss, University of Jos, 1999.

Ahmed, S. B. "Folklore as an academic discipline: An overview." Kakaki: Journal of English Studies 4 (2000): 186-9.

Akiga. Akiga's Story: The Tiv Peoples as seen by One of its Members. Translated and annotated by Rupert Moultrie East. London: OUP for International African Institute, 1965.

Aliyu, S. A. "An experience in the teaching of orature." Work in Progress 4 (1986): 51-6.

Anifowose, Remi and Francis C Enemuo. Elements of Politics, Oxford: Malthouse, 1999.

Babajo, A. K. Orature, Meaning, Nature and Forms: A Study Guide for Undergraduates. Kaduna: Slimline Publications, 2011.

Blake, Richard A. "Condominiums in the global village." Impact of Mass Media: Current Issues, Eds. Ray Eldon Hiebett and Carol Reuss. New York and London: Longman, 1985. 491-2.

Best, S. and D. Kellner. Postmodern Theory: Critical Interrogations. London: MacMillan, 1991.

Coplan, David. In the Time of Cannibals. The Word Music of South Africa's Basotho Migrants. Chicago: U of Chicago P, 1994.

Cohen, R. Theatre. California: Mayfield Publishing Company, 1994.

Collectif. Grains de parole: Puissance du verbe et traditions orales. Écrits pour Geneviève Calame-Griaule. Paris: Editions du Centre National de la Recherche Scienctifique, 1989.

Dexter, L. A. "Introduction." People, Society and Mass Communication. (eds.) Eds. L. A. Dexter and D. M. White. New York: The Free Press, 1964.

Finnegan, Ruth. "Literacy versus non-literacy: The great divide?" Modes of Thought, Essays on Thinking in Western and Non-Western Societies. Eds. Robert Horton and Ruth Finnegan. London: Faber and Faber, 1973. 112-44.

The Oral and Beyond: Doing Things with Words in Africa. Chicago: U of Chicago P, 2007.

Fox, Robert E. "Diasporacentricism and black aural texts." The African Diaspora. African Origins and New World Identities. Eds. Isidore Okpewho, Carole Boyce Davies, Ali Al'Amin Mazrui. Bloomington: Indiana U P, 1999. 367-78.

Goody, Jack and Ian Watt. "The Consequences of Literacy." Comparative Studies in Society and History 5.3 (1963): 304-45.

Gunner, Liz. "Africa and Orality." African literature: An Anthology of Criticism and Theory Eds. Tejumola Olaniyan and Ato Quayson. Malden: Blackwell, 2007. 67-73.

Hagher, Iyorwuese Harry. The Tiv Kwagh-Hir: A Popular Nigerian Puppet Theatre. Lagos: Centre for Black and African Arts and Civilization, National Theatre, c.1990.

Jordan, A. C. Towards a Literary Form in an African Literature: The Emergence Xhosa. Berkeley and Los Angeles: U of California P, 1973.

Jenkwe, Toryima Emma. Yanmuel Yashi: A Study of Tiv Oral Poetry. Aba: AAU Vitalis Book Company, 1998.

Ji, Tema. Interview with Godwin Aondofa Ikyer. Gboko, Benue State, Nigeria. 7 Nov. 2014.

Kaschula, Russel, H. "Imbongi to Slam: the emergence of a technologized auriture." African Languages Association of Southern Africa Conference, University of Stellenbosch, 2003.

Ker, Apegba. Tiv Poetry and Politics: A Study of Tarker Golozo. Abuja: Akia Books, 2002.

Kishani, Bongasu, T. "On the interface of philosophy and language in Africa: Some practical and theoretical considerations." African Studies Review 44.3 (2001): 27-45. 
Liman, Aliyu Abubakar. "Orature and multimedia: Exploring the interdisciplinary potentials of an emergent field." Journal of the Nigeria English Studies Association, 13.2 (2010): 125-36.

. "Re-negotiating the discursive limits of orature in the digital age." Conference of the English Department, Obafemi Awolowo University, Ile Ife, August 20-23 on the theme: "Language, Literature and Communication in the Globalised and Digital Age", 2012.

Merola, Daniela. "Introduction: Orality and technauriture of African Literatures." Tydskrif vir Letterkunde 51.1 (2014): 80-90. 2014. 20 Sept. 2014. < http://www.ajol.info/index.php/tvl/article/view/102250>.

Merola, Daniela, Jan Janson and Kamal Natt, eds. Multimedia Research and Documentation of Oral Genres in Africa- The Step Forward. Berlin: LIT Verlag, 2012.

Ngũgĩ wa Thiong'o. Globalectics: Theory and the Politics of Knowing. New York: Columbia U P, 2012.

Obadiah Kehemen Orkor. Manna: New Man. Makurdi, Benue State: Famous Global CD Tech. 2013. CD.

Okoh, Nkem. Preface to Oral Literature. Onitsha: Africana First Publishers, 2008.

Ong, Walter, J. Orality and Literacy: The Technologizing of the Word. New York: Methuen Press, 1982.

Peek, Philip M. "The Sounds of Silence: Cross-world communication and the auditory arts in African societies." American Ethnologist 21.3 (1994): 474-94.

Rice, Philip and Patricia Waugh, eds. Modern Literary Theory. New York: Hodder Arnold Publication, 1989.

Robert, G. A. and M. O. Jones. Folkloristics: An Introduction. Bloomington: Indiana U P, 1995.

Rosenberg, Bruce, A. "The Complexity of Oral Tradition." Oral Tradition 2.1 (1987): 73-90.

Swanepoel, C. F. "An Exploration of J. J. Moiloa's "Thesele, Ngwana Mmamokgatjhane," the epic tradition and the oral-written interface." Research in African Literatures 28.1 (1997): 112-23.

Utov with Ioratim-Uba. Christianity in Contemporary Tiv land: A Study in Challenges of Evangelization Facing the Church before and after the Great Jubilee Year 2000. Gboko: Jia Publicity Agency, 1998.

Wali, Obiajunwa. "The Dead End of African Literature." Transition 10 (1963): 13-5.

Zanga Zanga of Africa. Kerechocho. Gboko, Benue State: Franes Ventures, 2008. CD.

Zule-Zoo Musical Group. Kerewa. Lagos: Don Pedro Media, 2001. CD.

Zirimu, P. and Bukenya, A. "Oracy as a skill and as a tool for African development." The Arts and Civilization of Black and African Peoples 4. Lagos: Third Press International, 1986. 88-105

\section{Filmography}

Abraham, Praise. Nigerian Wuese Ter. Gboko: Praise Movies, s.d. CD.

Akpooki, Isaac. Ibumegh ki a Chigh Ga. Aliade, Benue State: Wajir Electronics and Entertainment, 2012. CD. Chia, Suemo. Adan Wade Kohol Ga. Gboko: Senator Suemo Chia, 2012. CD.

Emmanuel, Jikeme. Gbenda Awambe/Bloody is the Way. Gboko: Princess of Heaven International Christian Centre, 2012. CD.

Know My Name. Gboko, Benue State: Vision Entertainment, 2013. CD.

Kwa, Williams. Ikyese Kwaghyan. Gboko, Benue State: Golden Paradise Studios, 2012. CD.

Mba vegbe icaver kpa Terkoron Ve.NKST Media Services, Mkar, s.d. CD.

Mera, Usoh. Tiv legends: Sev Av. Sky Media Production Nig. Ltd, 2008. CD.

Oradiguve. NKST Media Services Mkar, s.d. CD.

Tartor Wase. Gboko: Praise Movies, s.d. CD.

Willas, Sammy. Igboji man Sule. Famous Global CD Tek, 2012. CD. 